\title{
Change in attitudes and knowledge of problem drug use and harm reduction among a community cohort in Kabul, Afghanistan
}

\author{
C.S. Todd, ${ }^{1}$ M.R. Stanekzai, ${ }^{2}$ A. Nasir, ${ }^{2}$ K. Fiekert, ${ }^{2}$ M.G. Orr, ${ }^{3}$ S.A. Strathdee ${ }^{4}$ and D. Vlahov ${ }^{5}$
}

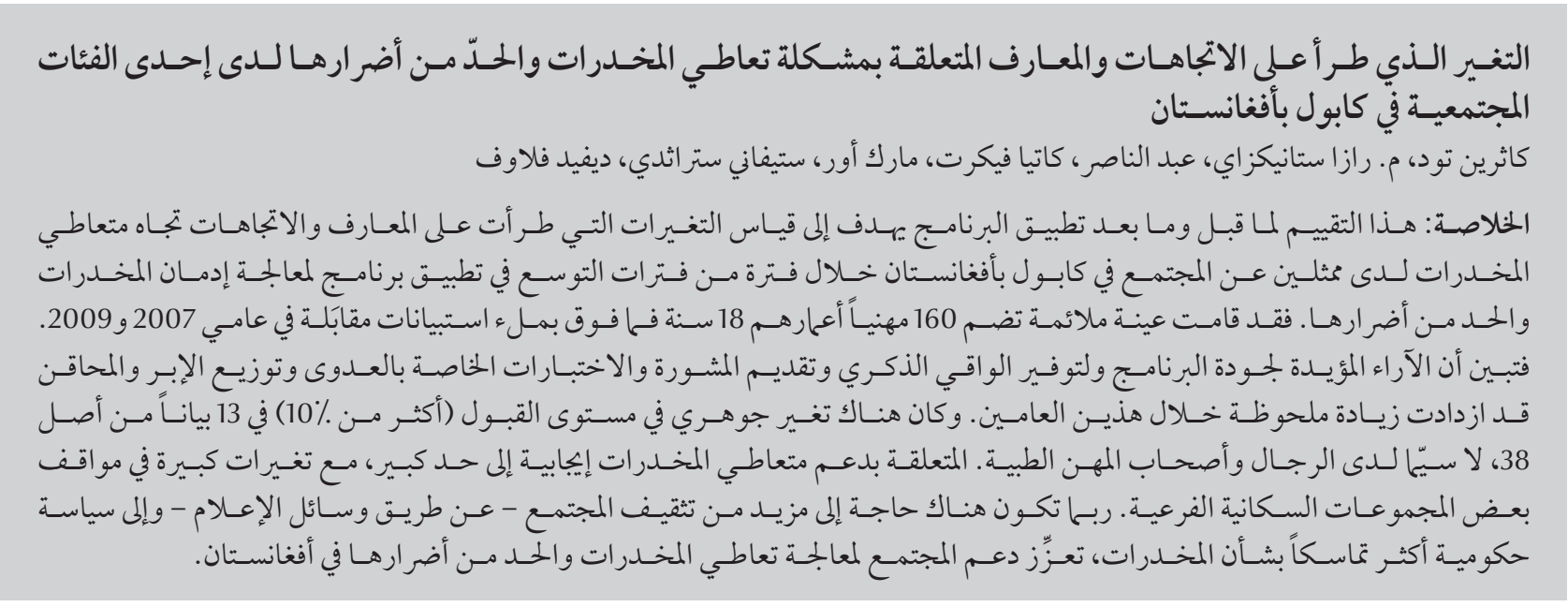

ABSTRACT This pre-post evaluation aimed to measure changes in knowledge and attitudes towards drug users among community representatives in Kabul, Afghanistan, over a period of expansion of harm reduction and drug dependence programming. A convenience sample of 160 professionals aged 18+ years completed interview questionnaires in 2007 and 2009. Views endorsing programme quality and the provision of condoms, infection counselling/testing and needle/syringe distribution increased significantly over the 2-year period. In 13 of 38 statements, there was a substantial $(>10 \%)$ change in agreement level, most commonly among men and medical professionals. Attitudes concerning support of drug users remained largely positive, with substantial attitude changes in some subgroups of the population. Further community education through the media and a more cohesive government drug policy may be needed to strengthen community support for harm reduction/drug treatment in Afghanistan.

Évolution des attitudes et des connaissances en matière de toxicomanies et de réduction des effets nocifs au sein d'une cohorte communautaire à Kaboul (Afghanistan)

RÉSUMÉ La présente évaluation pré-post visait à mesurer l'acquisition de connaissances et les changements d'attitudes à l'égard des toxicomanes parmi les représentants d'une communauté à Kaboul (Afghanistan) au cours d'une période d'élargissement des programmes de réduction des effets nocifs et de traitement de la dépendance aux drogues. Un échantillon de commodité de 160 professionnels âgés de plus de 18 ans a rempli des questionnaires dans le cadre d'entretiens en 2007 et en 2009. Les opinions au sujet de I'application de programmes de qualité et de la fourniture de préservatifs, du conseil et du dépistage en matière d'infections, ainsi que de la distribution d'aiguilles/de seringues se sont considérablement améliorées au cours de ces deux années. Dans 13 des 38 déclarations, on a pu noter un changement notable ( $>10 \%)$ dans le niveau d'acceptation, le plus souvent parmi les hommes et les professionnels de santé. Les attitudes concernant le soutien à apporter aux toxicomanes sont restées positives dans une large mesure, avec des changements d'attitude notables dans certains sous-groupes de la population. Une éducation plus poussée des communautés par le biais des médias et des politiques gouvernementales de lutte contre la drogue plus cohérentes sont nécessaires pour renforcer le soutien communautaire à la réduction des effets nocifs/au traitement des toxicomanies en Afghanistan. 


\section{Introduction}

Community support is an important component of successful drug dependence treatment and harm reduction programmes $(1-3)$. Studies among people who inject drugs indicate that perceived lack of support and stigma from the community or family can deter drug users from disclosing their HIV status or utilizing harm reduction services and can increase their feelings of isolation and propensity towards risky injecting behaviours (4-6). However, few studies have specifically assessed community attitudes toward drug use and harm reduction prior to or following introduction of harm reduction programmes. Hammett et al. found that knowledge and attitudes regarding harm reduction improved between baseline and 18 months post-intervention within the context of a community-wide structural intervention in both China and Viet Nam (2). Their assessment used cross-sectional sampling waves at each time point, rather than longitudinal data from the same individuals, thus limiting the ability of the study to attribute the effects to the intervention.

In Afghanistan, estimates indicate that problem drug use increased between 2005 and 2009 and that drug users, particularly those injecting opiates, tend to be concentrated in urban areas $(7,8)$. The subsequent donor response since 2007 has been to increase or expand the number of drug dependence treatment and harm reduction programmes and services $(9,10)$. Nevertheless, use of intoxicants is forbidden in Islam, and the current laws regarding drug use reflect this paradox, in that a first offence is eligible for treatment while repeat offenders are imprisoned (11). In a 2006 qualitative assessment of people who inject drugs in Kabul, many participants reported open condemnation by various community members and a sense of isolation and fear that coloured all interactions with the community at large (12). In 2007, we assessed community attitudes and knowledge about people who inject drugs (13). The findings highlighted some contradictory views; participants believed that drug use was motivated by criminal activity or moral weakness but they also agreed with statements indicating that drug addiction was a disease and indicated that they would be willing to participate in a programme to help drug users. Only 33\% correctly identified the legal implications of drug use in Afghanistan.

In the context of an increase both in the rate of problem drug use in the city and in the number of programmes for drug users in Kabul city, a follow-up assessment was carried out to evaluate changes in public perceptions over time. These data would be used to inform nascent harm reduction and drug dependence treatment programmes so that community relations and media programming could be modified to best support the public health objectives of these programmes. The specific objective of this study was to assess changes in community knowledge of and attitudes towards problem drug use and harm reduction and treatment programming among a community sample in Kabul, Afghanistan.

\section{Methods}

\section{Study design and setting}

This paper reports a pre- and post-interventionassessment of knowledge and attitudes among a sample of community representatives in Kabul, the capital of Afghanistan. Kabul is divided into 17 municipal districts and has an estimated metropolitan population of 5 million. In the last decade, the population has increased considerably due to returning refugees and to internal displacement secondary to conflict and other events (14). This assessment of community attitudes was part of a larger study conducted from June 2006 to November 2009 evaluating harm reduction use and risk behaviours among a cohort of people who inject drugs. During this period, media coverage and programmes for drug users increased substantially, as witnessed by an expansion of harm reduction programmes (based on needle and syringe collection and distribution) from 3 to 5, an increase of public, nocost drug treatment programmes from 3 to 6 , as well as an increase in the number of private treatment programmes.

The institutional review boards of the University of California, San Diego, Columbia University, and the Ministry of Public Health of the Islamic Republic of Afghanistan approved this study.

\section{Participants}

The eligibility criteria and recruitment of participants was described in the report of the baseline assessment in 2007 (13). A cross-sectional convenience sample of community representatives was recruited. Eligible participants were professionals (principally shop owners/workers, medical professionals and government officials) aged 18 years or more and residing in Kabul city. At enrolment during the baseline assessment, participants provided an address and telephone number which were used to contact them for the follow-up assessment. Of the 210 participants recruited at baseline, 160 completed the followup questionnaire.

\section{Data collection}

\section{Questionnaire}

The questionnaire instrument used for the baseline and follow-up data collection has been described previously (13). Briefly, this instrument collected information regarding attitudes toward drug use and appropriate treatment and also assessed knowledge of current drug laws and availability of treatment. In baseline and follow-up questionnaires, the same knowledge and attitude questions were used to ensure consistency. The long interval between completion of the two questionnaires likely minimized any bias secondary to repeated 
testing. Prior to baseline data collection, the draft instrument was pre-tested for content and face validity among 20 volunteers of different sexes, locations within Kabul city and professions. The study manager and principal investigator assessed the accuracy of the final changes to the questionnaire through back-translation.

\section{Study activities}

An interim analysis of the cohort data from the main study of drug users was performed in February 2009, 18 months following the initiation of enrolment. A results meeting was convened and attended by key government officials, civil society organization stakeholders and available community participants. This meeting included a presentation of the preliminary study results, a panel discussion with drug users and government officials, and speeches by an official from the Ministry of Public Health and a member of Parliament. Local media covered the event and portions of it were televised, potentially reaching community participants unable to attend.

In the month prior to the results meeting, the researchers contacted the participants from the baseline assessment of community attitudes; those contacted received a written invitation to the meeting. Following the results meeting in April 2009, study staff contacted participants and scheduled interviews at a site convenient to the participant starting in July 2009. Study staff confirmed the identity of the participant via the assigned study number and then administered the follow-up questionnaire. Participants were not compensated financially for their participation.

\section{Analysis}

Differences in sociodemographic characteristics between participants available for follow-up visits and those lost to follow-up were compared using the chi-squared and $t$-test, as appropriate.
Subsequent analysis considered only participants available at both study visits. Assessment of the change in awareness and knowledge of drug use over time was assessed with McNemar chi-squared and exact tests and paired $t$-tests, as appropriate.

Attitudes toward drug use and treatment were measured with Likert scales, with differences in level of agreement between baseline and follow-up analysed using Wilcoxon sign-rank test. Statements with less than $20 \%$ of participants differing from the majority were considered to have consensus. Consistent with the baseline analysis, the $80 \%$ mark was selected to highlight the most controversial positions $(13,15,16)$. For statements demonstrating $>10 \%$ change in consensus, sociodemographic and experiential (e.g. having a family member who was a drug user) factors were analysed with ordinal logistic regression to determine associations with changes in attitudes.

\section{Results}

Of 210 participants at baseline, 160 (72.7\%) completed the follow-up visit, of whom 39 (24.4\%) attended the results meeting. Participants retained in the study were more likely to be government $(P=0.03)$ and university officials $(P<0.01)$ than those who dropped out. Those who had lived outside Afghanistan within 5 years of enrolment were marginally more likely to complete the follow-up interview (79\% versus $66 \%, P=0.07)$, while younger participants (mean age at baseline 33.6 years versus 37.6 years, $P=0.02$ ), medical professionals $(P<0.01)$ and the police $(P=0.01)$ were less likely to complete both assessments. During the interval between baseline and follow-up, participants experienced some changes in employment status, with $6 \%$ gaining employment and $13 \%$ becoming unemployed $(P=0.04)$.

\section{Changes in perceptions towards drug users in Afghanistan}

Changes in perceptions and experiences towards drug users between baseline and follow-up for the 160 participants who completed both assessments are displayed in Table 1. At follow-up, significantly fewer individuals had encountered a drug user in the last 2 years (69.4\% compared with $84.4 \%$ at baseline, $P<0.01)$. Tobacco was now perceived to be the most commonly used illicit substance ( $58.1 \%$ versus $16.9 \%$ at baseline, $P<0.01$ ) whereas marijuana/ hashish were perceived as less common (19.4\% versus $45.6 \%$ at baseline, $P<$ $0.01)$. Perceptions regarding those at greatest risk for initiating drug use also changed, as prisoners and those working in heroin processing facilities were perceived to be at greater risk than 2 years earlier. All perceived reasons for initiating drug use (multiple answers allowed) were assessed. At follow-up, significantly more participants than at baseline believed that peer pressure and sadness over loss of home and family were reasons why people initiated drug use. Perceived harms associated with drug use (multiple answers permitted) showed that significantly fewer participants saw health-related problems (e.g. overdose, withdrawal and infections) as the greatest harms associated with drug use, while family disapproval and imprisonment increased as perceived harms.

\section{Knowledge and perceptions regarding appropriate response to drug use}

At follow-up, fewer participants (25.6\% versus $33.3 \%$ at baseline, $P=0.01$ ) stated that they knew the laws regarding drug use in Afghanistan. Of those claiming knowledge, only $41.0 \%(n=$ 22) correctly described that treatment was provided for the first offence (if available) and that those with subsequent offences were incarcerated (open-ended question). Participants 


\begin{tabular}{|c|c|c|c|c|c|}
\hline \multirow[t]{2}{*}{ Variable } & \multicolumn{2}{|c|}{ Baseline } & \multicolumn{2}{|c|}{ Follow-up } & \multirow[t]{2}{*}{$P$-value a } \\
\hline & No. & $\%$ & No. & $\%$ & \\
\hline Encountered a drug user in last 2 years & 135 & 84.4 & 111 & 69.4 & $<0.01$ \\
\hline Have a drug user in the family & 17 & 10.6 & 13 & 8.1 & 0.54 \\
\hline \multicolumn{6}{|l|}{ Most common drug used in Afghanistan } \\
\hline Tobacco & 27 & 16.9 & 93 & 58.1 & $<0.01$ \\
\hline Marijuana/hashish & 73 & 45.6 & 31 & 19.4 & $<0.01$ \\
\hline Opium/heroin & 44 & 27.5 & 27 & 16.9 & 0.01 \\
\hline Alcohol & 13 & 8.0 & 9 & 5.6 & 0.39 \\
\hline \multicolumn{6}{|l|}{ Group at greatest risk for drug use } \\
\hline Unemployed & 139 & 86.9 & 82 & 51.3 & $<0.01$ \\
\hline Prisoners & 2 & 1.3 & 27 & 16.9 & $<0.01$ \\
\hline Heroin processing facility workers & 5 & 3.1 & 14 & 8.8 & 0.06 \\
\hline Former/current soldiers & 2 & 1.3 & 13 & 8.0 & $<0.01$ \\
\hline Street children & 11 & 6.9 & 17 & 10.6 & 0.34 \\
\hline \multicolumn{6}{|l|}{$\begin{array}{l}\text { Most common perceived reason for initiating drug use } \\
\text { (multiple responses allowed) }\end{array}$} \\
\hline Peer pressure & 48 & 30.0 & 85 & 53.1 & $<0.01$ \\
\hline Frustration over unemployment & 105 & 65.6 & 82 & 51.3 & $<0.01$ \\
\hline Sadness over loss of family/home & 39 & 24.4 & 69 & 43.1 & $<0.01$ \\
\hline Enjoyment of the drug's effect & 59 & 36.9 & 42 & 26.3 & 0.04 \\
\hline Improve work output & 25 & 15.6 & 33 & 20.6 & 0.23 \\
\hline \multicolumn{6}{|l|}{ Perceived greatest harms associated with drug use } \\
\hline Family disapproval & 80 & 50.0 & 135 & 84.4 & $<0.01$ \\
\hline Imprisonment & 24 & 15.0 & 102 & 63.8 & $<0.01$ \\
\hline Overdose & 77 & 48.1 & 53 & 33.1 & $<0.01$ \\
\hline Infections (e.g. hepatitis) & 49 & 30.6 & 22 & 13.8 & $<0.01$ \\
\hline Withdrawal & 76 & 47.5 & 20 & 12.5 & $<0.01$ \\
\hline Violence from dealers/other users & 22 & 13.8 & 17 & 10.6 & 0.47 \\
\hline \multicolumn{6}{|l|}{ Types of treatment available for drug dependency $(n=132)$} \\
\hline Detoxification & 12 & 9.1 & 21 & 15.9 & 0.09 \\
\hline Inpatient hospital stay & 124 & 93.9 & 125 & 94.7 & 1.00 \\
\hline Medicines from pharmacy & 32 & 24.2 & 12 & 9.1 & $<0.01$ \\
\hline Counselling programmes & 42 & 31.8 & 85 & 64.4 & $<0.01$ \\
\hline Religious instruction & 32 & 24.2 & 28 & 21.2 & 0.53 \\
\hline \multicolumn{6}{|l|}{$\begin{array}{l}\text { Measures perceived as most important to reduce harm } \\
\text { to drug users }\end{array}$} \\
\hline Increased availability of dependency treatment & 146 & 91.3 & 141 & 88.1 & 0.47 \\
\hline Improved quality of dependency treatment & 55 & 34.4 & 74 & 46.3 & 0.02 \\
\hline Provision of vocational training & 129 & 80.6 & 127 & 79.4 & 0.77 \\
\hline $\begin{array}{l}\text { Provision of condoms and counselling and testing for } \\
\text { infections }\end{array}$ & 18 & 11.3 & 72 & 45.0 & $<0.01$ \\
\hline Increased imprisonment/sentences for drug users & 10 & 6.3 & 16 & 10.0 & 0.29 \\
\hline $\begin{array}{l}\text { Increased number of police in areas where drug users } \\
\text { congregate }\end{array}$ & 22 & 13.8 & 15 & 9.4 & 0.26 \\
\hline Provision of needles and syringes to those who inject & 18 & 11.3 & 31 & 19.4 & 0.03 \\
\hline Increased Islamic teaching about drug use & 83 & 51.9 & 68 & 42.5 & 0.08 \\
\hline
\end{tabular}

${ }^{a}$ McNemar or exact McNemar chi-squared test. 
were similarly asked about the most appropriate response towards drug use in Afghanistan, to which a variety of responses were elicited and categorized by content. Participants largely favoured medical treatment $(50.2 \%$ versus $49.5 \%$ at baseline), with lifestyle modification ( $25.1 \%$ versus $25.2 \%$ ) and counselling/ supportive care (20.0\% versus $16.4 \%$ ) also mentioned, with little change from baseline levels that were reported in an earlier paper (13). Fewer respondents ( $4.7 \%$ versus $16.4 \%$ at baseline) advocated punitive measures as the appropriate response to drug use.

\section{Awareness and attitudes toward harm reduction and addiction treatment}

Most participants remained aware that drug treatment programmes were available in Afghanistan (88.6\% at baseline, $87.5 \%$ at follow-up, $P=0.30$ ). At followup, participants had greater familiarity with counselling programmes (64.4\% versus $31.8 \%$ at baseline, $P<0.01)$ and detoxification programmes (15.9\% versus $9.1 \%$ at baseline, $P<0.09$ ), while less knowledge of obtaining medicines as a pharmacy for treatment $(24.2 \%$ versus $9.1 \%$ at baseline, $P<0.01)(\mathrm{Ta}-$ ble 1). When asked about which approaches were the most important to reduce harm to drug users, factors that were mentioned significantly more frequently than at baseline were: improving drug treatment quality, providing condoms and counselling and testing for infections, and providing needles and syringes to people who inject drugs (Table 1).

\section{Attitude scale results}

Participants were read 38 statements for which they indicated a level of agreement, measured by a Likert scale. Table 2 lists all the statements, the levels of consensus at baseline and follow-up, and the significance of changes from baseline. At follow-up, consensus (> 80\%) or approaching consensus (> 70\%) was present for 27 statements; of the 11 statements without consensus, 6 did not have consensus at baseline. However, 17 statements had statistically significant changes in individual scores between baseline and follow-up measures and 13 had substantial (>10\%) changes in overall levels of agreement. Factors significantly associated with $>10 \%$ change are shown in Table 3. Male participants and medical professionals were the groups most likely to have significant changes in levels of agreement over time, while loss of employment, attendance at the results meeting and age were not associated with changes between baseline and follow-up for any statement.

\section{Discussion}

The key findings of the study include increasingly positive perceptions of programmes for drug users (counselling and HIV testing programmes and needle/syringe collection and distribution schemes), and an increased belief in the association of drug-related harm with disintegration of family support. Both positive and negative shifts in overall attitudes over time among several groups of individuals were also detected at the end of the study period, although there was a reduction in self-professed knowledge of current drug use laws.

Increasing the availability of drug treatment and providing vocational training remained the most endorsed measures to aid drug users. The perceived value of needle and syringe collection and distribution programmes, of condom distribution and voluntary counselling and HIV testing programmes and of improved treatment programme quality increased over time. This change may reflect the increased numbers of programmes and the increased media coverage of drug use in urban Afghan settings, as well as programme efforts to educate and involve surrounding communities in their activities, similar to experiences reported in Viet Nam (1,2,10). However, despite positive changes in attitudes to the value of needle and syringe collection and distribution programmes and to counselling and testing, less than half of participants supported these measures. The smaller number of participants at follow-up reporting having encountered a drug user may have influenced these results.

Replies regarding the most appropriate response to drug use were consistent over time; the continued emphasis on medical treatment is reassuring and supports positive changes in the perceived benefits of drug treatment and harm reduction, potentially due to the greater number and visibility of such programmes in the community during the study period. The greatest perceived harms of drug use changed from health concerns to loss of social position, including family disapproval and imprisonment. This change may result from the increasing stress of burgeoning urban populations and resource scarcity on the family unit, the chief social support structure in Afghan society $(17,18)$. Keeping a drug user within the family unit likely equates to survival in the perceptions of many people, and removal of the drug user is thus perceived as a greater risk than ill health. More participants believed that sadness over loss of home and family or imprisonment were reasons for initiating drug use, and this change may also reflect fears surrounding displacement from the family unit. Drug use in prisons has been documented in various settings, including countries bordering Afghanistan, and knowledge of this has potentially permeated into the community (19-22). Peer pressure increased as a perceived reason to initiate drug use, perhaps due to media coverage of the issue or to respondents' direct experiences $(23,24)$.

One-third of attitude statements showed a substantial overall change in respondents' level of agreement, with 4 statements demonstrating potentially 


\begin{tabular}{|c|c|c|c|}
\hline \multirow[t]{2}{*}{ Statement } & \multicolumn{2}{|c|}{$\%$ agreeing } & \multirow[t]{2}{*}{$\boldsymbol{P}$-value ${ }^{\mathrm{t}}$} \\
\hline & Baseline & Follow-up & \\
\hline Drug use is increasing in Afghanistan & 96.2 & 96.3 & 0.21 \\
\hline Accessibility of opium and dealing drugs in Afghan society has increased & 92.4 & 98.1 & 0.01 \\
\hline Injecting drug use is increasing in Afghanistan & 73.8 & 80.0 & 0.06 \\
\hline Afghan culture is becoming more tolerant of drug use ${ }^{a}$ & 14.8 & 38.1 & $<0.01$ \\
\hline $\begin{array}{l}\text { Drug use in Afghanistan is directly related to the large amounts of opium } \\
\text { currently grown }\end{array}$ & 75.2 & 71.3 & 0.23 \\
\hline $\begin{array}{l}\text { The level of community awareness about drug use in Afghanistan is } \\
\text { adequate to address the problem }{ }^{\text {a }}\end{array}$ & 21.9 & 52.5 & $<0.01$ \\
\hline Drug addiction is motivated by criminal activity or moral weakness & 84.8 & 93.1 & 0.05 \\
\hline Drug addiction is a disease & 88.6 & 81.9 & \\
\hline Drug users are a danger to decent people & 93.8 & 88.7 & 0.98 \\
\hline $\begin{array}{l}\text { It is acceptable for families to cease relations with family members who use } \\
\text { drugs }\end{array}$ & 43.3 & 47.5 & 0.33 \\
\hline There are no circumstances under which drug use is acceptable & 84.3 & 93.1 & 0.02 \\
\hline Addiction causes people to turn to criminal activity to pay for drugs & 96.7 & 97.5 & 0.70 \\
\hline $\begin{array}{l}\text { Injecting drug users increase their risk of health problems by removing their } \\
\text { blood and replacing it with drugs }\end{array}$ & 90.0 & 83.8 & 0.18 \\
\hline Injecting drugs is worse than other kinds of drug use & 80.4 & 88.8 & 0.04 \\
\hline $\begin{array}{l}\text { Injecting drugs is advised to drug users by doctors to reduce the } \\
\text { dependence on drugs a }\end{array}$ & 26.2 & 39.4 & $<0.01$ \\
\hline Injecting drug use causes health problems like jaundice & 82.5 & 82.4 & 0.65 \\
\hline The greatest threat of drug users in society is the disintegration of the family & 89.5 & 93.1 & 0.86 \\
\hline Consumption of all intoxicating drugs is prohibited by Islam & 96.2 & 95.0 & 0.32 \\
\hline $\begin{array}{l}\text { Intoxicating substance use should be allowed in extreme cases of physical } \\
\text { or psychological pain }^{\text {a }}\end{array}$ & 56.7 & 13.8 & $<0.01$ \\
\hline Joblessness increases the risk someone will start using drugs & 95.2 & 98.1 & 0.21 \\
\hline $\begin{array}{l}\text { Women are more likely to use drugs as they are more easily influenced to } \\
\text { pursue the wrong behaviour }{ }^{\text {a }}\end{array}$ & 24.8 & 59.4 & $<0.01$ \\
\hline Afghan society and Islam both regard drug use to be a sin & 96.7 & 95.6 & 0.75 \\
\hline $\begin{array}{l}\text { Only religious leaders should help drug users through intensive prayer } \\
\text { sessions }^{\mathrm{a}}\end{array}$ & 55.2 & 37.5 & 0.01 \\
\hline Drug treatment centres should be established to help those with addiction & 95.2 & 97.5 & 0.32 \\
\hline $\begin{array}{l}\text { It is appropriate to use zakat money for the establishment of drug addiction } \\
\text { treatment }^{\mathrm{a}}\end{array}$ & 83.3 & 66.3 & $<0.01$ \\
\hline $\begin{array}{l}\text { Only families are obligated to get help and treatment for family members } \\
\text { who use drugs }\end{array}$ & 24.8 & 32.5 & 0.05 \\
\hline $\begin{array}{l}\text { Only the government is obligated to provide treatment services for people } \\
\text { who use drugs }{ }^{\mathrm{a}}\end{array}$ & 49.5 & 31.3 & $<0.01$ \\
\hline $\begin{array}{l}\text { Only religious leaders should decide what treatment is most appropriate for } \\
\text { drug users in Afghanistan }\end{array}$ & 12.4 & 17.5 & 0.07 \\
\hline $\begin{array}{l}\text { Eradication of poppy crops alone will be sufficient to control opium use in } \\
\text { Afghanistan }\end{array}$ & 49.5 & 56.3 & 0.22 \\
\hline $\begin{array}{l}\text { Community messages stating "Say no to drugs" alone will be sufficient to } \\
\text { prevent drug and alcohol use in Afghanistan }\end{array}$ & 16.7 & 46.9 & $<0.01$ \\
\hline $\begin{array}{l}\text { The entire community should be educated about the harms of drug use to } \\
\text { adequately prevent an increase drug use }\end{array}$ & 94.3 & 96.3 & 0.44 \\
\hline $\begin{array}{l}\text { Religious leaders and teachers should use their influence to increase } \\
\text { community awareness for drug use prevention }{ }^{\mathrm{a}}\end{array}$ & 87.2 & 97.5 & $<0.01$ \\
\hline
\end{tabular}




\begin{tabular}{|c|c|c|c|}
\hline \multirow[t]{2}{*}{ Statement } & \multicolumn{2}{|c|}{$\%$ agreeing } & \multirow[t]{2}{*}{$P$-value ${ }^{b}$} \\
\hline & Baseline & Follow-up & \\
\hline $\begin{array}{l}\text { Police should be a priority group to receive educational programming } \\
\text { about how to behave towards drug users }{ }^{\mathrm{a}}\end{array}$ & 83.8 & 97.5 & $<0.01$ \\
\hline I would be comfortable if a harm reduction centre opened near my home & 75.2 & 85.0 & 0.09 \\
\hline I would be comfortable participating in a programme to help drug users & 94.3 & 86.9 & $<0.01$ \\
\hline I am comfortable speaking with or praying next to drug users ${ }^{a}$ & 64.8 & 76.9 & 0.09 \\
\hline $\begin{array}{l}\text { I approve if any member of my family were to work with a programme to } \\
\text { help drug users }\end{array}$ & 77.1 & 88.8 & 0.11 \\
\hline I would be willing to hire or work with a former drug user & 80.0 & 84.4 & 0.43 \\
\hline
\end{tabular}

${ }^{a}$ Change of more than $10 \%$ in level of overall consensus for statement; ${ }^{b}$ Sign-rank test.

detrimental trends. Exposing participants to the preliminary results of harm reduction programmes - as recommended by a community assessment in Viet Nam and China-had no measurable impact on community representatives' attitudes in Kabul (2). Low attendance at the results meetings may have hindered sufficient dissemination of the programme findings to demonstrate an effect. There was increased agreement among respondents that community awareness of drug use was adequate to address problem drug use, thus reflecting the impact of expanded community-based and media efforts to publicize drug use in Afghanistan during the study period (10).

Our respondents had an increased odds of agreement with the statement that injecting drug use was recommended by health professionals as a way to reduce drug dependence. This may reflect misperceptions about appropriate drug treatment. However, during the study period, many private addiction "treatment" clinics became available, using pharmaceutical narcotics to replace illicit opioids and with a short-term oral course with a tapered dose provided at discharge. This regimen likely has a high failure rate and needs repeated courses of treatment, thus ensuring sustained profit for clinics (25). Our participants had a reduced level of agreement that it was appropriate to establish drug treatment centres with zakat - the tithing of income for charitable causes in Islam - and this may reflect increased awareness and negative community perceptions toward these private profitbased drug treatment clinics, potentially translating to negative perceptions of all drug treatment programmes. Negative views of using zakat for this purpose were more likely among shop owners, who may experience begging or concern for theft from drugs users which diminish their charitable feelings towards them.

The respondents in this study showed decreased support towards the use of intoxicants for patients in extreme pain. This is concerning, although it may reflect differences in interpretation of the question, which did not specify whether "intoxicating substances" included pharmaceutical opiates or other medicines. Respondents may have assumed that the question referred only to heroin and other opiates. Significant positive changes in responses to this statement occurred for those with a family member who was a drug user, potentially reflecting their greater understanding of drug dependency and its predisposing conditions. Participants with higher levels of education were more likely to change towards more negative attitudes, possibly reflecting trends toward conservative ideals based on exposure to the written and visual media. This issue would benefit from inquiry in future assessments because pharmaceutical intoxicant misuse is a common and under-recognized problem in Afghanistan (26).

Finally, the increased perception that women were particularly at risk for drug misuse may reflect some loss of ground for women's rights in Afghanistan. An article in the press reported approval of an edict officially describing women as second-class citizens (27), a belief increasingly espoused in the media and potentially accounting for the shift in attitude, which was significant among male participants, during the study period.

On a positive note, over time, participants reported increasing comfort interacting with drug users. However, the level of comfort significantly decreased for shop owners, as mentioned before. High levels of agreement persisted for statements reflecting comfort with harm reduction, willingness to hire former drug users as employees and willingness for themselves or a family member to participate in programmes to help drug users. This change is somewhat surprising given the reduced amount of contact with drug users over time, but may be attributable to media coverage of the growing problem of drug use and the positive profiles of some drug treatment centres within the media and community (10). 


\begin{tabular}{|c|c|c|c|c|}
\hline \multirow[t]{2}{*}{ Attitude statement/associated variables } & \multicolumn{2}{|c|}{ Mean score } & \multirow[t]{2}{*}{ OR } & \multirow[t]{2}{*}{$95 \% \mathrm{Cl}$} \\
\hline & Baseline & Follow-up & & \\
\hline \multicolumn{5}{|l|}{ Afghan culture is becoming more tolerant of drug use } \\
\hline No significant correlates & - & - & - & - \\
\hline \multicolumn{5}{|l|}{$\begin{array}{l}\text { The level of community awareness about drug use in Afghanistan is } \\
\text { adequate to address the problem }\end{array}$} \\
\hline Marital status (married) & 2.01 & 3.11 & 2.16 & $1.06-4.42$ \\
\hline Education (any secondary education) & 1.89 & 3.02 & 3.35 & $1.17-9.57$ \\
\hline \multicolumn{5}{|l|}{$\begin{array}{l}\text { Injecting drugs is advised to drug users by doctors to reduce the } \\
\text { dependence on drugs }\end{array}$} \\
\hline Occupation (medical professional) & 2.40 & 3.37 & 2.23 & $1.11-4.47$ \\
\hline \multicolumn{5}{|l|}{$\begin{array}{l}\text { Intoxicating substance use should be allowed in extreme cases of } \\
\text { physical or psychological pain }\end{array}$} \\
\hline Education (any secondary education) & 2.68 & 1.57 & 0.32 & $0.11-0.92$ \\
\hline Education (university education or higher) & 2.88 & 1.67 & 0.36 & $0.13-0.97$ \\
\hline Exposure (have family member who uses drugs) & 2.33 & 2.17 & 3.49 & $1.03-11.8$ \\
\hline \multicolumn{5}{|l|}{$\begin{array}{l}\text { Women are more likely to use drugs as they are more easily } \\
\text { influenced to pursue the wrong behaviour }\end{array}$} \\
\hline Sex (male) & 2.54 & 3.58 & 2.33 & $1.19-4.57$ \\
\hline \multicolumn{5}{|l|}{$\begin{array}{l}\text { Only religious leaders should help drug users through intensive } \\
\text { prayer sessions }\end{array}$} \\
\hline Sex (male) & 3.33 & 2.44 & 0.27 & $0.14-0.53$ \\
\hline Travel experience (lived outside Afghanistan in the last 5 years) & 2.88 & 2.97 & 2.13 & $1.05-4.34$ \\
\hline Occupation (shop owner/worker) & 2.92 & 3.36 & 2.52 & $1.16-5.47$ \\
\hline Occupation (medical professional) & 2.77 & 2.77 & 2.23 & $1.13-4.41$ \\
\hline \multicolumn{5}{|l|}{$\begin{array}{l}\text { It is appropriate to use zakat money for the establishment of drug } \\
\text { addiction treatment }\end{array}$} \\
\hline Occupation (shop owner/worker) & 3.92 & 3.00 & 4.47 & $1.95-10.3$ \\
\hline \multicolumn{5}{|l|}{$\begin{array}{l}\text { Only the government is obligated to provide treatment services for } \\
\text { people who use drug }\end{array}$} \\
\hline Sex (male) & 3.34 & 2.35 & 0.42 & $0.21-0.85$ \\
\hline Occupation (medical professional) & 2.57 & 1.83 & 2.79 & $1.38-5.64$ \\
\hline \multicolumn{5}{|l|}{$\begin{array}{l}\text { Community messages stating "Say no to drugs" alone will be } \\
\text { sufficient to prevent drug and alcohol use in Afghanistan }\end{array}$} \\
\hline Sex (male) & 1.93 & 2.79 & 2.98 & $1.33-6.66$ \\
\hline Marital status (married) & 2.03 & 2.81 & 2.38 & $1.04-5.43$ \\
\hline \multicolumn{5}{|l|}{$\begin{array}{l}\text { Religious leaders and teachers should use their influence to increase } \\
\text { community awareness for drug use prevention }\end{array}$} \\
\hline Sex (male) & 4.30 & 4.24 & 5.02 & $1.30-19.45$ \\
\hline \multicolumn{5}{|l|}{$\begin{array}{l}\text { Police should be a priority group to receive educational } \\
\text { programming about how to behave towards drug users }\end{array}$} \\
\hline Occupation (government official) & 3.87 & 4.65 & 3.22 & $1.33-7.82$ \\
\hline \multicolumn{5}{|l|}{ I am comfortable speaking with or praying next to drug users } \\
\hline Occupation (shop owner/worker) & 3.80 & 3.60 & 0.36 & $0.14-0.91$ \\
\hline \multicolumn{5}{|l|}{$\begin{array}{l}\text { I approve if any member of my family were to work with a } \\
\text { programme to help drug users }\end{array}$} \\
\hline No significant correlates & - & - & - & - \\
\hline
\end{tabular}

${ }^{a}$ Statements selected are those with $>10 \%$ change in consensus between baseline and follow-up measures. $O R=$ odds ratio; $C I=$ confidence interval. 
One further attitude statement merits mention, as significant differences were noted among 3 groups. Those who had lived outside Afghanistan were more likely to agree that only religious leaders should help drug users via intensive prayer sessions and this may be due to limited awareness of drug user programmes in Kabul. It is surprising that medical professionals also had a higher odds of endorsing this statement, as the mean attitude score did not change for this group. This lack of change may come from the high failure rates associated with drug treatment, fostering the opinion that spiritual therapy may be no worse than other treatment modalities (28). Shop owners and workers, who may have a more conservative outlook than those in other professions, had higher odds of agreement. By contrast, male participants, who have greater access to media and may travel freely, were less likely to endorse this view than were females, possibly reflecting their greater awareness of programme options and successes that did not involve religious instruction.

Some limitations to the study include the relatively low follow-up rate, which may have limited our ability to detect some associations, notably for several professional cadres, and may have inadvertently included individuals whose views did not reflect the majority of original participants. Concerted effort was made to locate the original participants, although turnover in the study staff during the study period may have compromised these attempts.
The follow-up questionnaire did not include questions eliciting specific sources for information that may have altered knowledge and attitude over time; the increased media attention on problem drug use and community outreach by harm reduction and treatment programmes may have had differential effects. Finally, quantitative data do not provide sufficient insight into reasons for attitude changes, leaving much room for conjecture. Further qualitative work is indicated to better delineate community perceptions surrounding drug misuse, harm reduction and treatment.

\section{Conclusions and recommendations}

In conclusion, the major finding from the study is that drug dependency in Kabul continues to be perceived by community representatives as a disease for which treatment and vocational training are the preferred response. Perceptions of the worst harm associated with drug use and the reasons for initiating drug use changed during the study period, as did the context of drug use and treatment in Kabul. Several trends in negative attitudes emerged that indicate a need for focused mediabased messages. Thus, the first recommendation emerging from the data is to address key negative attitudes measured within media and community-based messaging. One promising strategy is drama portraying the lived experience of drug users. A programme in the United States of America demonstrated increased community knowledge and participation in programmes for drug users after members of the community had viewed a play consisting of vignettes of drug users' life stories (28). Furthermore, drug treatment and harm reduction programmes could engage communities more widely or frequently, although migration within communities, limited programme staff and funding, and security limitations may make this approach untenable in Afghanistan, despite its success in other settings $(1,2)$. Finally, political will should be exercised to unify the disparate policy positions on drug use and treatment, and in particular those on harm reduction, between different sectors in the Afghan government (25).

\section{Acknowledgements}

We thank harm reduction programme colleagues of Médecins du Monde, Nejat Center and the Organization of Technical Cooperation for Community Development for their collaborative efforts. We appreciate the support of the Ministries of Counter-Narcotics and Public Health. We thank the participants for their time, input and trust.

Funding: This study was funded by a Clinical Scientist Development Award from the Doris Duke Charitable Foundation.

Competing interests: None declared.

\section{References}

1. Walsh N, Gibbie TM, Higgs P. The development of peer educator-based harm reduction programmes in Northern Vietnam. Drug Alcohol Rev. 2008 Mar;27(2):200-3. PMID:18264883

2. Hammett TM, Norton GD, Kling R, Liu W, Chen Y, Ngu D, et al. Community attitudes toward HIV prevention for injection drug users: findings from a cross-border project in southern China and northern Vietnam. J Urban Health. 2005 Sep;82(3) Suppl 4:iv34-42. PMID:16107438

3. Best practice in HIV/AIDS prevention and care for injecting drug abusers: the Triangular Clinic in Kermanshah, Islamic Republic of Iran. Cairo: World Health Organization Regional Office for the Eastern Mediterranean; 2004.
4. Rudolph AE, Davis WW, Quan VM, Ha TV, Minh NL, Gregowski A, et al. Perceptions of community- and family-level injection drug user (IDU)- and HIV-related stigma, disclosure decisions and experiences with layered stigma among HIV-positive IDUs in Vietnam. AIDS Care. 2012;24(2):239-44. PMID:21777075

5. Simmonds L, Coomber R. Injecting drug users: a stigmatised and stigmatising population. Int J Drug Policy. 2009 Mar;20(2):121-30. PMID:17981451

6. Rhodes T, Singer M, Bourgois P, Friedman SR, Strathdee $\mathrm{SA}$. The social structural production of HIV risk among injecting drug users. Soc Sci Med. 2005 Sep;61(5):1026-44. PMID:15955404 
7. Afghanistan drug abuse survey. Kabul, Afghanistan: United Nations Office on Drugs and Crime; 2005.

8. Drug use in Afghanistan: 2009 survey. Executive summary. Kabul, Afghanistan: United Nations Office on Drugs and Crime; 2010.

9. Saif-ur-Rehman, Rasoul MZ, Wodak A, Claeson M, Friedman J, Sayed GD. Responding to HIV in Afghanistan. Lancet. 2007 Dec 22;370(9605):2167-9. PMID:18156038

10. Maguet O, Majeed M. Implementing harm reduction for heroin users in Afghanistan, the worldwide opium supplier. Int J Drug Policy. 2010 Mar;21(2):119-21. PMID:20171864

11. Todd CS, Safi N, Strathdee SA. Drug use and harm reduction in Afghanistan. Harm Reduct J. 2005 Sep 7;2:13. PMID:16146577

12. Todd CS, Stibich MA, Stanekzai MR, Rasuli MZ, Bayan S, Wardak SR, et al. A qualitative assessment of injection drug use and harm reduction programmes in Kabul, Afghanistan: 2006-2007. Int J Drug Policy. 2009 Mar;20(2):111-20. PMID:18207381

13. Stanekzai MR, Todd CS, Orr MG, Bayan S, Rasuli MZ, Wardak SR, et al. Baseline assessment of community knowledge and attitudes toward drug use and harm reduction in Kabul, Afghanistan. Drug Alcohol Rev. 2012 Jun;31(4):451-60. PMID:21919980

14. Humanitarian update: Afghanistan-December 2010. Kabul, Afghanistan: United Nations Office for the Coordination of Humanitarian Affairs; 2011.

15. Raine S. Defining the Bobath concept using the Delphi technique. Physiother Res Int. 2006 Mar;11(1):4-13. PMID:16594311

16. Whitehead D. An international Delphi study examining health promotion and health education in nursing practice, education and policy. J Clin Nurs. 2008 Apr;17(7):891-900. PMID:18321288

17. Panter-Brick C, Goodman A, Tol W, Eggerman M. Mental health and childhood adversities: a longitudinal study in Kabul, Afghanistan. J Am Acad Child Adolesc Psychiatry. 2011 Apr;50(4):349-63. PMID:21421175

18. Dupree $\mathrm{NH}$. The family during crisis in Afghanistan. J Comp Fam Stud. 2004;35(2):311-31.

19. Boys A, Farrell M, Bebbington P, Brugha T, Coid J, Jenkins $R$, et al. Drug use and initiation in prison: results from a na- tional prison survey in England and Wales. Addiction. 2002 Dec;97(12):1551-60. PMID:12472639

20. Wood E, Lim R, Kerr T. Initiation of opiate addiction in a Canadian prison: a case report. Harm Reduct J. 2006;3:11. PMID:16542427

21. Zamani S, Farnia M, Torknejad A, Alaei BA, Gholizadeh M, Kasraee $F$, et al. Patterns of drug use and HIV-related risk behaviors among incarcerated people in a prison in Iran. J Urban Health. 2010 Jul;87(4):603-16. PMID:20390391

22. Kazi AM, Shah SA, Jenkins CA, Shepherd BE, Vermund SH. Risk factors and prevalence of tuberculosis, human immunodeficiency virus, syphilis, hepatitis B virus, and hepatitis C virus among prisoners in Pakistan. Int J Infect Dis. 2010 Sep;14 Suppl 3:e60-6. PMID:20189863

23. Rubin AJ, Rahimi S. Few treatment options for Afghans as drug use rises. The New York Times. 2011 Aug 27 (http:// www.nytimes.com/2011/08/28/world/asia/28kabul. html?pagewanted=all, accessed 29 January 2016).

24. Daneshmandan N, Narenjiha H, Tehrani K, Assari S, KhoddamiVishteh HR. Initiation to the first drug use among substance-dependent persons in Iran. Subst Use Misuse. 2011;46(9):1124-41. PMID:21345165

25. Todd CS, Macdonald D, Khoshnood K, Mansoor GF, Eggerman $M$, Panter-Brick C. Opiate use, treatment, and harm reduction in Afghanistan: recent changes and future directions. Int J Drug Policy. 2012 Sep;23(5):341-5. PMID:22717389

26. Macdonald DS. Briefing paper series: Afghanistan's hidden drug problem: the misuse of psychotropics. Kabul, Afghanistan: Afghanistan Research and Evaluation Unit; 2008.

27. Hamid Karzai under fire on Afghan women's rights. The Telegraph. 20128 Mar (http://www.telegraph.co.uk/news/ worldnews/asia/afghanistan/9130508/Hamid-Karzai-underfire-on-Afghan-womens-rights.html, accessed 29 January 2016).

28. Joe GW, Simpson DD, Broome KM. Effects of readiness for drug abuse treatment on client retention and assessment of process. Addiction. 1998 Aug;93(8):1177-90. PMID:9813899

Authors' affiliations continued from page 183

${ }^{2}$ Health Protection and Research Organization, Kabul, Afghanistan.

${ }^{3}$ Heilbrunn Department of Population and Family Health, Mailman School of Public Health, New York, United States of America.

${ }^{4}$ Centre for Urban Epidemiologic Studies, The New York Academy of Medicine, New York, United States of America.

${ }^{5}$ Division of Global Public Health, University of California San Diego School of Medicine, La Jolla, California, United States of America. 